\title{
ПРОБЛЕМНО ОРІЄНТОВАНА ЛЕКЦІЯ-КОНФЕРЕНЦІЯ 3 ЕЛЕМЕНТАМИ ВИПЕРЕДЖАЮЧОГО НАВЧАННЯ ТА ВІЗУАЛІЗАЦЇ̈ ЗА ТЕМОЮ “СИНДРОМ АБДОМІНАЛЬНОГО БОЛЮ У ДІТЕЙ” У ДОДИПЛОМНІЙ ПІДГОТОВЦІ ЛІКАРІВ
}

О. Л. Ковальчук

Наиіональний медичний університет імені О. О. Богомольия, м. Київ

\author{
PROBLEM-ORIENTED LECTURE-CONFERENCE WITH THE \\ ELEMENTS OF PROACTIVE TRAINING AND VISUALIZATION ON \\ "SYNDROME OF ABDOMINAL PAIN IN CHILDREN" IN THE \\ UNDERGRADUATE TRAINING OF PHYSICIANS
}

\author{
O. L. Kovalchuk
}

National Medical University by O. O. Bohomolets, Kyiv

\begin{abstract}
У статті відображено сучасні уявлення про нетрадиційні методи навчання, зокрема організації проблемної лекції. Підкреслено, що проблемна лекція спирається на логіку послідовно модельованих проблемних ситуацій шляхом постановки проблемних питань або пред'явлення проблемних завдань. Виділено основні етапи організації і проведення проблемної лекції з елементами візуалізації, зроблено акцент на проблемні та інформаційні питання. Показано, що проблемна лекція активізує навчально-пізнавальну діяльність студентів, їх самостійну роботу, посилює професійну підготовку майбутніх лікарів.
\end{abstract}

Reflects modern ideas concerning non-traditional teaching methods, in particular the problem of organizing a topical lecture. It is emphasized that the topical lecture is based on the logical consequence of simulated problematic situations by asking questions or setting problematic tasks. The basic stages of organization and delivering topical lecture with elements of visualization have been defined with the emphasis on problem solving and information issues. It is shown that the topical lectures activate learning and cognitive activity of students, their independent work, enhances the professional training of future physicians.

Вступ. У вищому медичному закладі при усному викладенні навчального матеріалу в основному використовують словесні методи навчання. Серед них важливе місце продовжує займати лекція, тому що у підручнику переважно викладається найбільш загальний, фундаментальний матеріал навчальної програми. Проте традиційна вузівська лекція має ряд недоліків, а саме: привчає студентів до пасивного сприйняття чужих думок, механічного записування слів лектора; гальмує самостійне мислення студентів; зменшує прагнення студентів до самостійних занять [2].

Відмова від лекції взагалі не лише може знизити науковий рівень підготовки майбутніх лікарів, але i порушити системність і рівномірність їх роботи протягом навчального року. Отже, лекція, як і раніше,

(c) О. Л. Ковальчук повинна залишитися як провідним методом навчання, так і провідною формою організації навчального процесу у вищому медичному навчальному закладі. Вказані ж вище недоліки значною мірою можуть бути здолані при вживанні нетрадиційних видів читання лекцій, наприклад проблемних лекцій, бінарних лекцій, лекцій-провокацій, лекцій-конференцій, лекцій-консультацій і ін. Зрозуміло, що всі вони приводять до зміни ролі і функції викладача $[1,2]$.

У зв'язку з цим актуальність застосування нетрадиційних методів навчання, зокрема проблемних лекцій, очевидна [3, 8].

Основна частина. Методика читання проблемної лекції полягає в тому, що викладач пропонує студентам проаналізувати ситуацію і здійснити пошук шляхів знаходження проблеми. Проблемна лекція спирається на логіку послідовно модельованих проблем- 
них ситуацій шляхом постановки проблемних питань або пред'явлення проблемних завдань, що вимагають активної пізнавальної діяльності для їх правильної оцінки і рішення, і зазвичай починається з питань і постановки проблеми, яку в ході викладу матеріалу необхідно вирішити. Проблемні питання відрізняються від непроблемних тим, що прихована в них проблема вимагає неоднотипного рішення, оскільки готової схеми для їх вирішення в минулому досвіді студентів немає, отже, для відповіді на них потрібний ряд міркувань, тоді як для непроблемного питання вже існує правило, яке необхідно знати.

Що стосується змісту, то на відміну від змісту традиційної лекції, в якій інформація підноситься викладачем у вигляді відомого матеріалу, на проблемній лекції нове знання вводиться як невідоме для студентів. Відповідно, отримана інформація засвоюється як особисте відкриття ще невідомого для себе знання, що дозволяє створити у студентів ілюзію “відкриття" вже відомого в науці $[1,2]$. Навчальна проблема ставиться викладачем до лекції і повинна розвертатися на лекції в живій мові викладача, оскільки проблемна лекція передбачає діалогічний виклад матеріалу [2, 3].

Успішність досягнення цілей проблемної лекції забезпечується взаємодією викладача і студентів, оскільки основне завдання викладача полягає не лише в передачі інформації, а в поясненні студентам об'єктивних протиріч розвитку наукового знання і способів їх рішення, що, у свою чергу, формує мислення студентів, викликає їх пізнавальну активність.

У зв'язку з тим, що здібність до самостійного мислення формується під час різних форм живого мовного спілкування, лекції проблемного характеру необхідно доповнювати практичними заняттями у вигляді дискусії та діалогічними формами самостійної спільної роботи студентів [7]. Для управління ж мисленням студентів на проблемній діалогічній лекції використовуються заздалегідь складені викладачем проблемні і інформаційні питання.

Проблемні питання - питання, відповідь на які не міститься в колишніх знаннях студентів і які викликають у них інтелектуальні труднощі [6]. Інформаційні питання задаються з метою актуалізувати вже наявні знання у студентів, необхідні для розуміння проблеми і початку пошуку шляхів іiі вирішення. Вважається, що лише поєднання проблемних і інформаційних питань може розвивати індивідуальні особливості кожного студента

Засоби візуалізації покращують сприйняття чогось нового, дозволяють посилити збереження отриманої інформації в пам’яті, демонструють естетичні вимоги та потреби суб'єкта навчального процесу [3]. Проблемна лекція ставить освітні та виховні цілі та допомагає у їх вирішенні [5].

Пропонуємо розглянути методичний сценарій проблемної лекції з елементами візуалізації на тему “Синдром абдомінального болю у дітей” (табл. 1). По-перше, визначається актуальність теми, що аргументується поширеністю проблеми абдомінального болю у дітей за рахунок функціональних розладів шлунково-кишкового тракту, як прояву психосоматичної патології, складністю діагностики причин абдомінального болю і виправданості комбінування психотерапії та медикаментозного лікування синдрому абдомінального болю у дітей. По-друге, презентується мета лекції: 1) формування базових знань для подальшого засвоєння студентами навчального матеріалу з теми “Синдром абдомінального болю у дітей"; 2) розвиток сучасних наукових поглядів студентів на епідеміологію, етіологію, класифікацію, клініку, діагностику, лікування і профілактику синдрому абдомінального болю у дітей; 3) на основі міжпредметної інтеграції (табл. 2) формування у студента цілісного сприйняття проблеми синдрому абдомінального болю у дітей; 4) посилення мотивації студентів до навчання шляхом активної дискусії та залучення до інтерактивної участі в ході проведення проблемної лекції, що розкриває їх творчі здібності i науковий потенціал; 5) формування у студентів відчуття співавторства, дослідницького пошуку у підготовці та проведенні проблемної лекції; 6) вироблення у студента критичного, логічного, клінічного мислення; 7) формування почуття відповідальності за виконання конкретного проблемного завдання в ході підготовки до лекції, розвиток комунікативних здібностей, компетенції.

План лекції: 1. Розповсюдженість абдомінального болю у дітей. 2. Механізми виникнення абдомінального болю. 3. Класифікація абдомінального болю у дітей. 4. Діагностичні критерії та клінічні прояви функціональних розладів органів травлення у дітей (Римські критерії III, 2006 p). 5. Діагностичні критерії та клінічні прояви органічних розладів органів травлення у дітей. 6. Лікувальна тактика при синдромі абдомінального болю у дітей.

До проблемних питань, які опрацьовують студенти для інтерактивної участі в ході лекції, можна віднести:

1. Патофізіологія больового відчуття. На основі пошукової роботи з літературними джерелами та знань з базових дисциплін (міждисциплінарна інтеграція)-патологічної фізіології(механізми формування 
Таблиця 1. Методичний сценарій впроваджуваної технології/методу

\begin{tabular}{|c|c|c|c|c|}
\hline $\begin{array}{c}\text { № } \\
3 \mathrm{a} / \Pi\end{array}$ & $\begin{array}{c}\text { Етапи та їх } \\
\text { функції }\end{array}$ & Дії викладача & Дії студента & $\begin{array}{c}\text { Методичне } \\
\text { забезпечення }\end{array}$ \\
\hline I & $\begin{array}{c}\text { Підготовчий } \\
\text { етап }\end{array}$ & $\begin{array}{l}\text { 1. Складання плану лекції. } \\
\text { 2. Здійснення літературного пошуку } \\
\text { за темою лекції. } \\
\text { 3. Визначення проблемних питань } \\
\text { лекції. } \\
\text { 4. Визначення розділів матеріалу } \\
\text { для опрацювання студентами та } \\
\text { інтерактивної участі в ході лекції. } \\
\text { 5. Підготовка наочностей у вигляді } \\
\text { презентації та відеоматеріалів. } \\
\text { 6. Підготовка клінічних випадків. } \\
\text { 7. Визначення } 3 \text { груп студентів для } \\
\text { виконання конкретних завдань } 3 \\
\text { підготовки окремих питань за } \\
\text { темою лекції та інтерактивної участі } \\
\text { у проблемній лекції. } \\
\text { 8. Визначення питань для студентів } \\
\text { та переліку літератури для } \\
\text { підготовки до лекції. } \\
\text { 9. Розробка алгоритму оцінювання } \\
\text { студентів }\end{array}$ & $\begin{array}{l}\text { 1. Ознайомлення } 3 \\
\text { переліком питань для } \\
\text { підготовки до лекції. } \\
\text { 2. Опрацювання } \\
\text { рекомендованої } \\
\text { літератури. } \\
\text { 3. Підготовка розділів } \\
\text { матеріалу для } \\
\text { інтерактивної участі } \\
\text { в лекції. } \\
\text { 4. Відновлення знань } 3 \\
\text { базових дисциплін у межах } \\
\text { міжпредметної інтеграції, } \\
\text { виділення для себе } \\
\text { проблемних моментів, } \\
\text { підготовка запитань } \\
\text { лектору. } \\
\text { 5. Підготовка учасниками } \\
\text { інтерактивних груп } \\
\text { коротких презентацій із } \\
\text { заданих викладачем } \\
\text { проблемних питань }\end{array}$ & $\begin{array}{l}\text { Текст лекції, } \\
\text { презентація, } \\
\text { відеоматеріал, } \\
\text { унаочнення } \\
\text { (фотографії, схеми, } \\
\text { малюнки), клінічні } \\
\text { ситуації, список } \\
\text { основних та додат- } \\
\text { кових літературних } \\
\text { джерел }\end{array}$ \\
\hline II & $\begin{array}{c}\text { Основний } \\
\text { етап }\end{array}$ & $\begin{array}{l}\text { 1. Викладення матеріалу лекції. } \\
\text { 2. Демонстрація презентації та } \\
\text { відеоматеріалів (ефект візуалізації). } \\
\text { 3. Окреслення проблемних питань } \\
\text { діагностики функціональних } \\
\text { захворювань органів травлення у } \\
\text { дітей, що виносяться для активного } \\
\text { обговорення з аудиторією (вислови- } \\
\text { ти свою думку, обгрунтувати } \\
\text { запропоноване рішення). } \\
\text { 4. Аналіз окремих моментів } \\
\text { клінічних випадків. } \\
\text { 5. Залучення студентів до } \\
\text { інтерактивного викладення окремих } \\
\text { розділів теми лекції }\end{array}$ & $\begin{array}{l}\text { 1. Ознайомлення з лек- } \\
\text { ційним матеріалом. } \\
\text { 2. Участь в обговоренні } \\
\text { проблемних питань } \\
\text { (клінічних ситуацій) в ході } \\
\text { викладення матеріалу } \\
\text { лекції. } \\
\text { 3. Демонстрація } \\
\text { підготовлених матеріалів } \\
\text { з окремих розділів лекції } \\
\text { за методикою “навчання } \\
\text { з випередженням”. } \\
\text { 4. Обговорення заданих } \\
\text { проблем, висловлення } \\
\text { своєї думки для їх вирі- } \\
\text { шення, обгрунтування їі }\end{array}$ & $\begin{array}{l}\text { Текст лекції, } \\
\text { відеоматеріал, } \\
\text { фотографії, схеми з } \\
\text { запитаннями та } \\
\text { елементами їх вирі- } \\
\text { шення, малюнки, } \\
\text { тести з варіантами } \\
\text { відповіді, клінічні } \\
\text { ситуації з } \\
\text { еталонами відпо- } \\
\text { відей, список } \\
\text { основних та додат- } \\
\text { кових літературних } \\
\text { джерел }\end{array}$ \\
\hline III & $\begin{array}{c}\text { Підсумковий } \\
\text { етап }\end{array}$ & $\begin{array}{l}\text { 1. Підведення підсумків } \\
\text { інтерактивної проблемної лекції. } \\
\text { 2. Оцінка пошукової роботи } \\
\text { студентів та викладення ними } \\
\text { матеріалу. Подяка за співпрацю. } \\
\text { 3. Відповідь на запитання, які } \\
\text { виникли у студентів у ході лекції. } \\
\text { 4. Пропонування додаткових } \\
\text { джерел інформації по темі лекції. } \\
\text { Формулювання подальших } \\
\text { проблемних питань на самостійне } \\
\text { опрацювання студентами }\end{array}$ & $\begin{array}{l}\text { Виділення невирішених } \\
\text { завдань та розробка шляхів } \\
\text { їх подолання за допомогою } \\
\text { лектора }\end{array}$ & $\begin{array}{l}\text { Основні та } \\
\text { додаткові джерела } \\
\text { інформації для } \\
\text { вирішення питань, } \\
\text { які виникли в } \\
\text { процесі } \\
\text { обговорення. } \\
\text { Завдання для } \\
\text { активних студентів. } \\
\text { Завдання на } \\
\text { самостійне } \\
\text { опрацювання }\end{array}$ \\
\hline
\end{tabular}


Таблиця 2. Міждисциплінарна інтеграція

\begin{tabular}{|l|l|}
\hline \multicolumn{1}{|c|}{ Назва дисциплін } & \multicolumn{1}{c|}{ Отримані навички } \\
\hline Анатомія & Анатомічні особливості органів травлення у дітей різного віку \\
\hline Фізіологія & Фізіологія секреторної та моторної активності ШКТ, їх регуляція \\
\hline Патофізіологія & $\begin{array}{l}\text { Патофізіологія основних порушень секреції та моторики органів } \\
\text { травлення, їх регуляції }\end{array}$ \\
\hline Гістологія та ембріологія & $\begin{array}{l}\text { Особливості розвитку органів травлення в онтогенезі. Гістологічна будова } \\
\text { органів травлення }\end{array}$ \\
\hline Мікробіологія & Мікробіологічний пейзаж кишківника в нормі та при патології \\
\hline Пропедевтика дитячих хвороб & $\begin{array}{l}\text { Характерні скарги при захворюваннях органів травлення у дітей, основні } \\
\text { методи діагностики патології травної системи, основні клінічні синдроми. } \\
\text { Вміти зібрати анамнез, виявити скарги, провести загальний огляд, клінічне } \\
\text { обстеження }\end{array}$ \\
\hline Фармакологія & $\begin{array}{l}\text { Фармакокінетика та фармакодинаміка основних лікарських засобів, які } \\
\text { використовуються при лікуванні синдрому абдомінального болю у дітей }\end{array}$ \\
\hline
\end{tabular}

больового відчуття, механізми стресу), пропедевтики педіатрії (анатомо-фізіологічні особливості нервової системи, ендокринної регуляції, шлунково-кишкового тракту у дітей) група студентів представляє концептуальну модель болю та больової поведінки у дітей.

2. Класифікація абдомінального болю. На основі пошукової роботи з літературними джерелами групі студентів пропонується представити класифікацію абдомінального болю у дітей за критеріями: а) тривалості; б) за походженням; в) у зв'язку з характером ураження ШКТ.

3. Регуляція рухової активності ШКТ. На основі пошукової роботи з літературними джерелами та знань з базових дисциплін (міждисциплінарна інтеграція) - нормальної та патологічної фізіології група студентів представляє механізми регуляції рухової активності кишківника та патогенез спазму гладкої мускулатури шлунково-кишкового тракту [4].

Під час основного етапу лекції формулюються проблемні питання основного етапу. Студентам пропонуються клінічні випадки з типовими проявами захворювання. Сутністю проблеми є встановлення діагнозу за клінічними діагностичними критеріями. Еталони відповідей надаються після обговорення.

Для інформаційних питань потемі проблемноїлекції “Синдром абдомінального болю у дітей” можна запропонувати: 1) розповсюдженість абдомінального болю у дітей; 2) механізми виникнення абдомінального болю; 3 ) класифікація абдомінального болю у дітей; 4) механізми рухової активності ШКТ у дітей; 5) діагностичні критерії та клінічні прояви функціональних розладів органів травлення у дітей (Римські критерії III, 2006 р.); 6) діагностичні критерії та клінічні прояви органічних розладів органів травлення у дітей; 7) тактика сімейного лікаря при органічних розладах органів травлення у дітей; 8) механізм дії спазмолітичних препаратів; 9) лікувальна тактика при функціональних розладах органів травлення у дітей [4].

На заключному етапі лекції студентам у якості проблемного питання пропонується самостійно доопрацювати питання ролі психотерапії в лікуванні функціональних захворювань органів травлення у дітей.

Для критеріїв оцінки пошукової роботи студентів та інтерактивної участі в лекції пропонується таке: доповідь, презентація на всіх членів команди: 3 помилками - 2 бали, неповна - 3 бали, достатня -4 бали. Доповідач +1 бал. Питання під час обговорення: несуттєве - 1 бал, суттєве - 2 бали. Відповідь на запитання неповна - 1 бал, повна - 2 бали. Гіпотеза діагнозу захворювання: необгрунтована - 1 бал, обгрунтована - 2 бали. Бали можуть бути зараховані як оцінка індивідуальної самостійної роботи студента або, якщо вона не передбачена в модулі, додаватися до оцінки підсумкового модульного контролю.

Отже, проблемні лекції забезпечують творче засвоєння принципів і закономірностей науки, що вивчається, активізують навчально-пізнавальну діяльність студентів, їх самостійну роботу, засвоєння знань і вживання їх на практиці. На лекції проблемного характеру студенти знаходяться в постійному процесі “співмислення" з викладачем i, зрештою, стають співавторами у вирішенні проблемних завдань.

Висновок. Таким чином, знання, засвоєні студентами під час проблемних лекцій, стають надбанням студентів, тобто якоюсь мірою знаннями-переконаннями; глибше запам'ятовуються і легко актуалізуються (повчальний ефект); гнучкіші і володіють властивістю перенесення в інші ситуації (ефект розвитку творчого мислення); вирішення проблемних завдань виступає своєрідним тренажером у розвит- 
ку інтелекту (розвиваючий ефект); зазначена лекція підвищує інтерес до змісту і підсилює професійну

\section{Списоклітератури}

1. Бордовская Н. В. Педагогика : учебник для вузов / Н. В. Бордовская, А. А. Реан. - СПб. : Питер, 2000 - 304 с.

2. Казданян С. Ш. Проблемная лекция как словесный метод нетрадиционного обучения в вузе / С. Ш. Казданян // Проблемы и перспективы развития образования в XXI веке: профессиональное становление личности (философские и психолого-педагогические аспекты) : материалы Международной научно-практической конференции, 10-11 апреля 2011 года. - Пенза ; Ереван ; Прага : Научно-издательский центр “Социосфера”, 2011.- С. 233-238.

3. Компетентностно-ориентированное обучение в медицинском вузе : учебно-методическое пособие / [А. И. Артюхина, Н. А. Гетман, М. Г. Голубчикова и др.] ; под ред. Е. В. Лопановой. - Омск : ООО “Полиграфический центр КАН", 2012.-198 c. підготовку (ефект психологічної підготовки до майбутньої діяльності).

4. Кривопустов С. П. Проблемно ориентированная педиатрия: избранные вопросы (клиническое руководство для врачей) / С. П. Кривопустов. - Х. : Новое слово, 2012. -288 c.

5. Психологія та педагогіка: підручник / [ М. Б. Максименко, С. Д. Свтух, В. В. Коваленко та ін.] ; за ред. С. Д. Максименка. - К. : Слово, 2013. -578 с.

6. Махмутов М. И. Проблемное обучение: основные вопросы теории / М. И. Махмутов. - М. : Педагогика, 1975. $-368 \mathrm{c}$.

7. Мілерян В. С. Методичні основи підготовки та проведення навчальних занять у медичних вузах : метод. посібник / В. Є. Мілерян. - К. : Хрещатик, 2006. -80 с.

8. Мухина С. А. Современные инновационные технологии обучения / С. А. Мухина, А. А. Соловьева. - М. : ГЭОТАР-МЕДИА, 2008.-360 с. 